\title{
Migration of the Common Redstart (Phoenicurus phoenicurus)
} \section{a Eurasian songbird wintering in highly seasonal conditions in the West African Sahel} Willemoes, Mikkel; Tøttrup, Anders P.; Thorup, Kasper

Published in:

The Auk: Ornithological Advances

DOI:

10.1525/auk.2013.13001

Publication date:

2013

Document version

Publisher's PDF, also known as Version of record

Document license:

Unspecified

Citation for published version (APA):

Willemoes, M., Tøttrup, A. P., \& Thorup, K. (2013). Migration of the Common Redstart (Phoenicurus

phoenicurus): a Eurasian songbird wintering in highly seasonal conditions in the West African Sahel. The Auk: Ornithological Advances, 130(2), 258-264. https://doi.org/10.1525/auk.2013.13001 


\section{Migration of the Common Redstart (Phoenicurus phoenicurus): A Eurasian Songbird Wintering in Highly Seasonal Conditions in the West African Sahel}

Author(s): Mikkel Willemoes Kristensen, Anders P. Tøttrup, and Kasper Thorup

Source: The Auk, 130(2):258-264.

Published By: The American Ornithologists' Union

URL: http://www.bioone.org/doi/full/10.1525/auk.2013.13001

BioOne (www.bioone.org) is a nonprofit, online aggregation of core research in the biological, ecological, and environmental sciences. BioOne provides a sustainable online platform for over 170 journals and books published by nonprofit societies, associations, museums, institutions, and presses.

Your use of this PDF, the BioOne Web site, and all posted and associated content indicates your acceptance of BioOne's Terms of Use, available at www.bioone.org/page/terms_of_use.

Usage of BioOne content is strictly limited to personal, educational, and non-commercial use. Commercial inquiries or rights and permissions requests should be directed to the individual publisher as copyright holder. 


\title{
MIGRATION OF THE COMMON REDSTART (PHOENICURUS PHOENICURUS): A EURASIAN SONGBIRD WINTERING IN HIGHLY SEASONAL CONDITIONS IN THE WEST AFRICAN SAHEL
}

\author{
Mikkel Willemoes Kristensen, ${ }^{1,3}$ Anders P. Tøttrup, ${ }^{2}$ and Kasper Thorup ${ }^{1}$ \\ ${ }^{1}$ Center for Macroecology, Evolution and Climate, Natural History Museum of Denmark, University of Copenhagen, Universitetsparken 15, \\ DK-2100 Copenhagen, Denmark; and \\ ${ }^{2}$ Center for Macroecology, Evolution and Climate, Department of Biology, University of Copenhagen, Universitetsparken 15, \\ DK-2100 Copenhagen, Denmark
}

\begin{abstract}
AвSTRACT.-Some species of long-distance migrant birds are thought to follow spatiotemporal patterns of high food availability during the non-breeding season, a strategy termed "itinerancy," instead of being sedentary in one specific site. We tracked the migration of a small Eurasian songbird, the Common Redstart (Phoenicurus phoenicurus), using archival light-level geolocators. The birds showed a distinct counterclockwise loop migration from northern Europe. Fall migration passed west of the Mediterranean Sea and along the northwest African coast before the birds made an abrupt change of direction at the southern edge of the Sahara toward the winter area farther inland in the West African Sahel. Spring migration was more direct: north to the Iberian Peninsula and back to northern Europe. The birds spent more time in only one winter site than they do during the breeding season in northern Europe, and they generally showed no signs of itinerancy-except for one bird that probably avoided an exceptional drought. Their arrival on the winter grounds was well timed with peak vegetation greenness, assumed to reflect food availability, but vegetation greenness declined rapidly during their stay, and resource availability was relatively low throughout most of the non-breeding season. Despite the highly seasonal conditions in the wintering area, itinerancy is apparently not an optimal strategy for the Common Redstart, possibly because of timing constraints. Alternatively, food availability may not be closely linked to vegetation greenness. Received 3 January 2013, accepted 8 March 2013.
\end{abstract}

Key words: Common Redstart, itinerancy, migration, Phoenicurus phoenicurus, winter ecology, Zugknick.

\section{Migration de Phoenicurus phoenicurus : un oiseau chanteur eurasien hivernant dans des conditions très saisonnières dans le Sahel ouest africain}

RÉSUMÉ.-On croit que certaines espèces aviaires migrant sur de longues distances suivent des patrons spatiotemporels de grande disponibilité alimentaire en dehors de la saison de reproduction, une stratégie appelée "itinérance », au lieu d'être sédentaires en un site spécifique. Nous avons suivi la migration d'un petit oiseau chanteur eurasien, Phoenicurus phoenicurus, à l'aide de géolocalisateurs. Les oiseaux ont présenté une migration en boucle distincte en sens antihoraire à partir du nord de l'Europe. La migration automnale des oiseaux passait par l'ouest de la mer Méditerranée et le long la côte nord-ouest africaine avant de changer abruptement de direction à l'extrémité sud du Sahara vers l'aire d'hivernage située plus loin à l'intérieur des terres dans le Sahel ouest africain. La migration printanière était plus directe : en direction nord vers la péninsule ibérique puis vers l'Europe du Nord. Les oiseaux ont passé plus de temps sur un seul site d'hivernage qu'ils ne le font au cours de la saison de reproduction en Europe du Nord et ils ne présentaient généralement aucun signe d'itinérance - sauf un oiseau qui a probablement évité une sécheresse exceptionnelle. Leur arrivée sur les aires d'hivernage est bien synchronisée avec le pic de verdure de la végétation, qui est supposé refléter la disponibilité de nourriture, mais la verdure de la végétation a rapidement décliné au cours de leur séjour et la disponibilité des ressources était relativement faible pendant la majeure partie de la saison hivernale. Malgré les conditions fortement saisonnières sur l'aire d'hivernage, l'itinérance ne semble pas être une stratégie optimale pour P. phoenicurus, probablement en raison de contraintes de temps. Par ailleurs, la disponibilité de la nourriture n'est pas étroitement liée à la verdure de la végétation.

${ }^{3}$ E-mail: mwkristensen@snm.ku.dk

The Auk, Vol.130, Number 2, pages 258-264. ISSN 0004-8038, electronic ISSN 1938-4254. @ 2013 by The American Ornithologists' Union. All rights reserved. Please direct all requests for permission to photocopy or reproduce article content through the University of California Press's Rights and Permissions website, http://www.ucpressjournals. com/reprintInfo.asp. DOI: 10.1525/auk.2013.13001 
MANY SPECIES OF migrant birds spend a much larger proportion of their life away from than on the breeding area (e.g., Beason et al. 2012, Tøttrup et al. 2012b). For many of those wintering in tropical Africa and South America, little is known about their basic ecology and behavior during the non-breeding season. Some species travel from their temperate breeding ground to a single non-breeding location and stay there until they return in spring, whereas others move between different non-breeding locations. The latter phenomenon, termed "itinerancy," is known to occur in Africa (Moreau 1972, Pearson and Backhurst 1976), where several species travel long distances during winter (e.g., Tøttrup et al. 2012b). Itinerancy is only just beginning to be described in the New World migration system in recent tracking studies of Veeries (Catharus fuscescens), Swainson's Thrushes (C. ustulatus), and Purple Martins (Progne subis) (Heckscher et al. 2011, Delmore et al. 2012, Fraser et al. 2012; see additional papers in this special feature).

Most migrating birds move between different stopover areas, but Jones (1995) separated stopovers in itinerancy from regular migration stopovers by their duration. Regular migration stopovers are necessary for refueling after flying long distances, but if a bird stays for longer, the stopover is not a necessity but simply more advantageous than continuing immediately to the next site. On the basis of observations of species presence, Jones (1995) stated that itinerant stopovers typically last 1-2 months but individual stopover duration is most likely shorter. Moreau (1972) considered only longer stopovers in the tropics itinerant behavior.

Itinerant behavior is believed to be a response to patterns of rainfall, with birds continuously optimizing their access to food by being present in the best season of the seasonal habitats they occupy. We therefore predict that itinerancy will occur when birds are wintering in seasonal habitats and that a seasonal period of high productivity does not last through the entire non-breeding season. Bell $(1996,1997)$ predicted that migrating birds experience better non-breeding conditions in the peak period in a highly seasonal habitat than in a habitat with constant high productivity. This is based on the assumption of lower competition with local residents in seasonal environments, because the effective population size of residents is regulated by the food availability during the low-productivity periods (Ashmole's hypothesis; Ashmole 1963, Lack and Moreau 1965). The important point is the difference between food availability during a low and a high period (excess food availability), rather than the absolute peak amount of food. The timing of the peak is also important, though, and Bell $(1996,1997)$ predicted that only birds that depart the winter area late enough to benefit from a spring peak in food availability will migrate longer distances to reach the area with that peak. Similarly, only birds that depart the winter area late enough to benefit from moving during winter should be itinerant.

Most temperate breeding birds wintering in West Africa are "winter-sedentary," but some show itinerancy. Trierweiler et al. (2013) reported that individual Montagu's Harriers (Circus pygargus) followed patterns of vegetation presence that presumably reflect food availability, and a similar pattern has been found in Lesser Kestrels (Falco naumanni; Catry et al. 2011). Less is known of itinerancy in passerines. Salewski et al. (2002) interpreted the higher mobility during the winter in Willow Warblers (Phylloscopus trochilus) than in Pied Flycatchers (Ficedula hypoleuca) as a sign of itinerancy in the former, although the scale of their movement was unknown. Hedenström et al. (1993) found clear signs of itinerancy in Great
Reed Warblers (Acrocephalus arundinaceus) in Ghana. No study has investigated the seasonality in resource availability for the passerines, primarily because no knowledge about individual full-season migratory movements has been available.

The Common Redstart (Phoenicurus phoenicurus) is a widespread Eurasian passerine that breeds in continental Europe, the British Isles, Scandinavia, and eastward to $\sim 110^{\circ}$ and is a common wintering bird in West Africa. It is a cavity breeder in the family Muscicapidae and feeds on insects typically taken on the ground, on tree trunks, or in the air (Cramp 1988). Most Common Redstarts winter in Africa in the Sahel zone from the coast of Senegal in the West to the coast of Eritrea in the East. Both Jones (1995) and Moreau (1972) reported the Common Redstart as itinerant on the basis of data indicating that Common Redstarts arrive in Nigeria substantially later than they leave Europe (Fry 1965, Elgood et al.1966), which suggests that they linger for a period somewhere in between.

We tracked the migration of adult Common Redstarts breeding in Northern Europe through their annual cycle. We investigated whether the birds showed signs of itinerancy and related this to patterns of food availability using a vegetation index as a proxy.

\section{Methods}

Field work.-We tracked 5 adult Common Redstarts breeding in eastern Denmark $\left(55.86^{\circ} \mathrm{N}, 12.37^{\circ} \mathrm{E}\right)$. The birds were breeding in nest boxes in a study area dominated by open forest with mainly oaks (Quercus robur and Q. petraea), Silver Birch (Betula pendula), European Beech (Fagus sylvatica), and Norway Spruce (Picea abies). Around 200 nest boxes are within an area of 30 ha, supporting a stable population of Common Redstarts ( 10 pairs). The birds were captured when their chicks were $\sim 7$ days old, either with a trap in the nest box or with mist nets outside the box. Two birds were tracked in 2 consecutive years, totaling 7 tracks. The birds were tracked using stalkless Mk20s archival light geolocators $(0.6 \mathrm{~g})$ from the British Antarctic Survey (Afanasyev 2004). The loggers were fitted on the birds using a leg-loop harness made from 1-mm braided nylon string (Naef-Daenzer 2007). Nine birds ( 5 males and 4 females) were equipped with loggers in 2010 , and 4 of them ( 3 males and 1 female) returned in 2011. Eight birds (5 males and 3 females) were equipped with loggers in 2011, and 3 (all males) returned in 2012.

Analysis of geolocator data.-The geolocator data were analyzed using the BASTRAK software suite (Fox 2010). We defined sunrises and sunsets using the threshold method, with a sun angle estimated for each individual. We used a threshold level of 2 (arbitrary units) and found the individual corresponding sun angle (range: $-3.5^{\circ}$ to $-1^{\circ}$ ) by calibrating the data during the breeding season because this is where the birds' locations were known. If the birds were stable throughout winter, we estimated the winter location as the average position during December and January, when there is little influence from the equinoxes. Because most of the migratory movement coincides with the periods around the equinox, we removed only 7 days on each side of the equinox and then deleted all outlier latitudes, defined as positions north of the breeding grounds or south of the estimated winter latitude. If $\geq 5$ positions were left during a stopover, these were used to estimate the latitude, whereas longitude was estimated using all longitudes during the stopover. All birds followed fall routes that led them far west of the winter site before they made an easterly turn to reach their destination (except for one bird that stayed near the 
Atlantic coast during the winter). The latitude of this directional change could be determined only in 2 tracks. In the remaining 5 tracks, the latitude was set to values in between the latitudes of the 2 known points (for illustrative purposes only), whereas the longitudes were measured.

Temporal development in non-breeding-season food availability and itinerancy.-As a measure of net primary productivity and, thus, a proxy for differences in food availability between months, we used the eMODIS normalized differentiation vegetation index (NDVI; Pettorelli et al. 2005). Values were extracted every half month for the area where the birds spent the non-breeding season from a $0.1^{\circ}$-resolution data set. We examined NDVI on all stopovers that were $>10$ days. This is shorter than our definition of itinerancy (see below), but all longer stopovers could potentially be specifically timed to the seasonality of an area. Values were extracted for the period 2000-2010 for each stopover point as the mean within a buffer of $0.5^{\circ}$ radius around the points. All values from the same half month (varying year and bird) were averaged to produce an average yearly progression in available resources at that specific stopover. This was compared with the number of birds present during a year. Extraction of NDVI values to the winter points were done in the Geospatial Modeling Environment (Beyer 2012). We defined a bird as itinerant if it had $>1$ stopover of $\geq 20$ days of length in the tropics. We defined the stopovers using longitudes, because these are more accurate than latitudes and not affected by equinox (Hill 1994, Fudickar et al. 2012, Lisovski et al. 2012). To evaluate whether longitude changed while a bird was south of the Sahara, we did a runs test (Zar 2010), which determines whether the points are randomly distributed above or below the mean. Significant results indicate that there are continuous periods when the bird was above or below the mean longitude, indicating that the bird moved during the period. We calculated this on a data set with a longitude from every second day. This was to avoid the effect of autocorrelation, because the positions on 2 consecutive days will depend on the same midnight estimation and therefore be interrelated. A significant runs test can arise for either of two reasons: (1) the bird moved during the period of interest (itinerancy), creating one or few abrupt changes of longitude; or (2) there was an artifact in the data that resulted in a specific error pattern. Errors can appear as either a gradual and slow change in longitude (trend) or as constantly shifting short periods of continuous values either above or below the mean (leading to a high degree of autocorrelation). To distinguish between the two possible explanations, we visually checked for an abrupt change in longitude during the period of interest. If no abrupt change was found, we checked for a significant trend and tested for autocorrelation using a Durbin-Watson test (Durbin and Watson 1950). All statistical tests were performed in R, version 2.14.0 (R Development Core Team 2011), and maps were created using ARCGIS (ESRI, Redlands, California). Results are presented \pm SD.

\section{RESULtS}

Annual migration.-Fall migration routes were west of the Mediterranean through northern West Africa to longitudes that were an average of $9 \pm 4^{\circ}$ west of the winter site longitudes. With the exception of 1 bird, the birds then made an abrupt directional change toward the winter sites. The exception stayed near the Atlantic coast (Fig. 1). Six of the 7 tracks had two different fall stopovers. The first lasted an average of $7 \pm 3$ days, and the second averaged $13 \pm 5$ days. Both stopover sites were in either southwest Europe or northwest Africa (for timing, see Table 1).

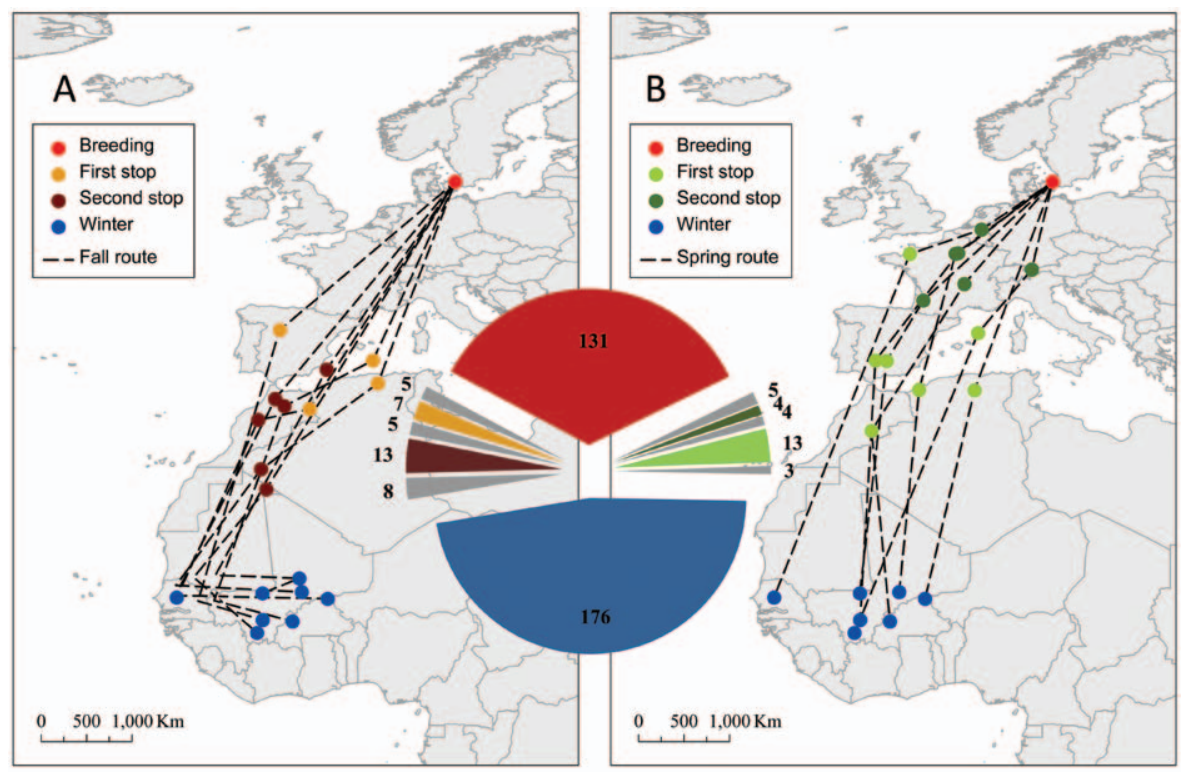

FIG. 1. (A) Fall and (B) spring migration routes and stopover sites (see inset legends) of 7 tracks of Common Redstarts banded in Denmark in 2010 and 2011 and tracked using archival light-level geolocators. Lines connect stopover sites and do not necessarily represent routes followed. During fall migration all birds moved far west of their wintering site before arrival. This is illustrated by the directional changes in the fall routes, reflecting the actual longitudes reached. Inset pie chart shows the average number of days spent in each step of the migratory cycle; color scheme is the same as for stopovers, with gray indicating movement periods. 
TABLE 1. Minimum, maximum, median, and standard deviation (SD) in departure (dep) and arrival (arr) dates of the migratory cycle of Common Redstarts banded in Denmark in 2010 and 2011 and tracked using archival light-level geolocators.

\begin{tabular}{lcccc}
\hline Spatial stage & Minimum & Maximum & Median & SD (days) \\
\hline Breeding dep & 14-Aug & 15-Sep & 28-Aug & 10 \\
Autumn stop1 arr & 23-Aug & 24-Sep & 03-Sep & 11 \\
Autumn stop1 dep & 02-Sep & 28-Sep & 08-Sep & 10 \\
Autumn stop2 arr & 09-Sep & 04-Oct & 11-Sep & 10 \\
Autumn stop2 dep & 20-Sep & 11-Oct & 25-Sep & 8 \\
Winter arr & 26-Sep & 17-Oct & 01-Oct & 9 \\
Winter dep & 02-Mar & 19-Apr & 03-Apr & 16 \\
Spring stop1 arr & 07-Mar & 23-Apr & 05-Apr & 16 \\
Spring stop1 dep & 03-Apr & 29-Apr & 16-Apr & 9 \\
Spring stop2 arr & 05-Apr & 01-May & 16-Apr & 9 \\
Spring stop2 dep & 10-Apr & 03-May & 20-Apr & 8 \\
Breeding arr & 13-Apr & 08-May & 22-Apr & 9 \\
\hline
\end{tabular}

The return migration route was directly northward from the winter area to the Iberian Peninsula and then northeast to Northern Europe. Six of 7 tracks had 2 stopovers lasting $13 \pm 10$ days and $4 \pm 1$ days, respectively. The first was around the western Mediterranean and the second in western Central Europe. In both spring and fall, two tracks could potentially have crossed the Mediterranean farther east (for individual full-year tracks, see online supplementary material [Acknowledgments]).

The winter sites were in southern Mali and northern Burkina Faso, with 1 bird near the Atlantic coast in Senegal; the winter area spanned a total of $15^{\circ}$ longitude. The birds spent $176 \pm 16$ days in the winter area. For 2 birds, we knew the breeding arrival and departure dates for 2011, and their time spent on the breeding ground in that year was 134 and 127 days. Neither of these 2 was winter-site faithful. They moved $12^{\circ}$ and $3^{\circ}$ longitude east, respectively, from the first to the second year. Comparing only males, the birds had a significantly later departure from the winter site in 2012 than in 2011 (mean = 14 March 2011, $n=3$; mean = 7 April $2012, n=3 ; t=2.85 ; P=0.046$ ) and similar but nonsignificant later arrival to the breeding grounds (means $=17$ April 2011; mean $=29$ April 2012; $t=2.64, P=0.057$; Table 2).

Temporal development in non-breeding-season food availability and itinerancy.-The arrival at the second autumn stopover did not coincide with any peaks in vegetation, because the peak in this area occurred in early spring (Fig. 2). In the winter area, NDVI peaked in the first half of September, approximately 2-4 weeks before the birds

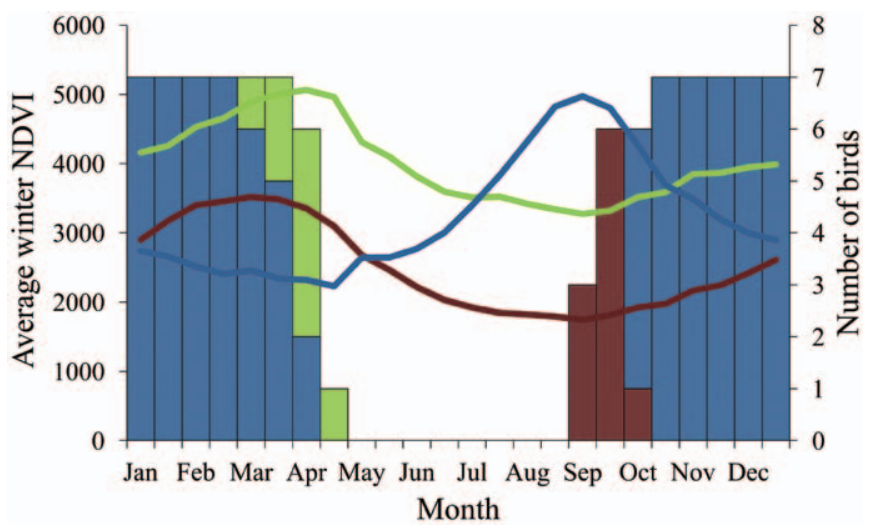

FIG. 2. Average values of eMODIS normalized differentiation vegetation index (NDVI) for the 3 sites where birds spent $>10$ days (curves), for Common Redstarts banded in Denmark in 2010 and 2011 and tracked using archival light-level geolocators. The NDVI is used as a proxy for plant productivity. Site occupancy is illustrated as number of birds present in the winter area (bars). Color scheme is the same as in Figure 1, where dark brown is second autumn stopover, blue is winter, and light green is first spring stopover.

arrived. NDVI declined sharply in the fall, leveled out with a slow decline during winter, and reached minimum values in the last half of April, just after the birds departed on spring migration. On the first spring stopover, NDVI peaked in the first half of April, which was also the period with the highest number of birds present.

Five of the 7 tracks showed no sign of itinerancy during winter (Table 3). Among the 2 remaining tracks, 1 (003) showed no abrupt change in either longitude or latitude, strong autocorrelation (Durbin-Watson: $D=1.5, P<0.0001$ ), and a slight, negative trend $\left(-0.005^{\circ}\right.$ day $\left.^{-1}, P=0.001\right)$. In the other track (009), there was an abrupt shift in longitude of $4^{\circ}$ on 12 March and a simultaneous change in latitude, indicating movement during early spring. This second winter site was estimated $\sim 420 \mathrm{~km}$ to the southwest of the first one, and the bird stayed there for 34 days.

\section{Discussion}

We described the migration route and wintering sites of a small temperate breeding songbird wintering in the tropics, based on archival light-level geolocator tracking. Both spring and fall migration included two short stopovers and crossed the Mediterranean

TABLE 2. Comparison between 2011 and 2012 of departure from the winter area and arrival on the breeding site by male Common Redstarts banded in Denmark in 2010 and 2011 and tracked using archival light-level geolocators. Individuals in the top two rows are the same in both years. The winter area was affected by a heavy drought during the winter of 2011-2012.

\begin{tabular}{|c|c|c|c|c|c|c|}
\hline ID & $\begin{array}{c}\text { Winter } \\
\text { departure } \\
2011\end{array}$ & $\begin{array}{c}\text { Winter } \\
\text { departure } \\
2012\end{array}$ & $\begin{array}{l}\text { Difference } \\
\text { (days) }\end{array}$ & $\begin{array}{c}\text { Breeding } \\
\text { arrival } \\
2011\end{array}$ & $\begin{array}{c}\text { Breeding } \\
\text { arrival } \\
2012\end{array}$ & $\begin{array}{l}\text { Difference } \\
\text { (days) }\end{array}$ \\
\hline $273=007$ & 14-Mar & 03-Apr & 20 & 13-Apr & 21-Apr & 8 \\
\hline $277=009$ & 27-Mar & 18-Apr & 22 & 19-Apr & 07-May & 18 \\
\hline 278 & 02-Mar & & & 19-Apr & & \\
\hline 003 & & 02-Apr & & & 30-Apr & \\
\hline Average & 14-Mar & 07-Apr & 24 & 17-Apr & 29-Apr & 12 \\
\hline
\end{tabular}


TABLE 3. Results of runs tests on longitudes while birds were south of the Sahara, for Common Redstarts banded in Denmark in 2010 and 2011 and tracked using archival light-level geolocators. Significant results indicate nonrandom distribution above or below mean winter longitude, meaning that the birds had likely moved between different longitudes during that time (i.e., were itinerant).

\begin{tabular}{|c|c|c|}
\hline ID & $\begin{array}{c}\text { Runs test } \\
(z)\end{array}$ & $P$ \\
\hline 003 & -2.654 & 0.008 \\
\hline 007 & -0.266 & 0.790 \\
\hline 009 & -8.085 & 0.000 \\
\hline 273 & -0.217 & 0.828 \\
\hline 276 & -0.410 & 0.682 \\
\hline 277 & -0.526 & 0.599 \\
\hline 278 & -1.591 & 0.112 \\
\hline
\end{tabular}

at the western end. During fall migration the birds ventured far west of the winter site and made a large directional change just south of the Sahara. The birds wintered in the West African Sahel, mainly in southern Mali, and did not show signs of itinerancy despite strong seasonality in this area.

The latitudes of the stopovers are highly uncertain because they coincide with the equinoxes. On the basis of longitudinal data, the two fall stopovers appear to be in southwestern Europe and in northwestern Africa. In spring, there is a stopover around the western Mediterranean and a second in southwestern Central Europe. The large change of direction ("Zugknick") after crossing the Sahara in fall follows the overall pattern traced by migrating songbirds in West Africa as tracked by radar (Liechti et al. 2012) and of Honey Buzzards (Pernis apivorus) as tracked by satellite (Hake et al. 2003). Their direction was southward through the Sahara but more easterly near the southern edge of the desert. The detour of the birds in the present study, which occurred when they reached longitudes averaging $9^{\circ}$ west of their final destination before turning east, was $\sim 1,000 \mathrm{~km}$. Why birds make this detour is not known, but it may be that it allowed them to avoid crossing the Atlas Mountains (Liechti et al. 2012).

The main wintering area spanned almost the entire West African Sahel. This low level of migratory connectivity is consistent with descriptions in the literature; birds at the western end of the winter range are purported to originate from both the eastern and western parts of the breeding range (Blondel 1967, Moreau 1972). Neither of the 2 birds that were tracked in successive years returned to the same winter site. A few examples of high fidelity to winter sites exist (Elgood et al. 1966, Moreau 1972), but Moreau (1972) reports that only 3 of 90 banded Common Redstarts returned to a former winter site, which suggests low winter-site fidelity.

That the birds had only two shorter stopovers en route and generally stayed in the same location throughout the winter contradicts suggestions of itinerancy in the species (Moreau 1972, Jones 1995). The abrupt change in both longitude and latitude during early spring in 1 individual was not typical, in that it was observed only in that individual and only in 1 of 2 years that it was tracked (2012). The bird moved $>400 \mathrm{~km}$ southwest at a time of year when the birds generally started migrating toward Europe in 2011; this singular movement was perhaps caused by the heavy drought in the main wintering area in the West African Sahel in 2012 (United Nations 2012). A dramatic drought in stopover areas before a desert crossing delayed departure toward Europe in two passerine species (Tøttrup et al. 2012a), and this may explain why the birds in this study departed the winter site notably later in 2012 than in 2011.

Environmental conditions experienced during the non-breeding season cannot explain the choice of the longest autumn stopover site, but most likely there are no places in Europe or Africa north of the Sahara that have a vegetation peak at this time. The first spring stopover arrival seems well timed with a peak in vegetation. This is not the same as itinerancy by our definition, because the stopover is too short, but it might partly explain the timing of the winter departure. The main wintering area was highly seasonal, and NDVI values dropped (from peak to bottom) by $\sim 50 \%$ during the birds' stay. Thus, movement during winter could have improved conditions, similar to what other species do in the same region, but is apparently not optimal for Common Redstarts. There are probably many possible reasons why they do not move during winter, including physiological constraints and risk aversion, but most likely a combination of several factors explains this behavior. Two possible explanations that follow from predictions in the literature deserve note. One is that the birds are constrained by timing, and the other is that a species with the flycatcher's foraging style is not strongly affected by seasonal changes in vegetation. In respect to the first, a peak in food availability occurs in April farther south in West Africa (Bell 1996), but the normal departure date of Common Redstarts is too early to benefit from this peak. Following predictions of Bell (1996, 1997), we should therefore not expect them to move south during winter. In respect to the second, in Africa the Common Redstart feeds mainly on insects taken on the ground (Moreau 1972). Such foraging is almost exclusively limited to the drier, more northern sub-Saharan habitats in the Sahel region during the non-breeding season (Pearson and Lack 1992). The efficiency of such foraging may be less influenced by seasonal conditions than in leaf-gleaners that probably depend more on insects that feed on green leaves (Lack 1986), and NDVI may not reflect true food availability for such foragers. Foraging type was suggested as a driver of interspecific differences in reactions to seasonal variations, causing intratropical migration in some species of Middle American songbirds (Morton 1977) and itinerancy in the Veery (Heckscher et al. 2011).

These results illustrate the complexity of the winter ecology for the temperate-breeding migrants that winter in the tropics. In South America, intratropical migration is well known (Jahn et al. 2004, Faaborg et al. 2010), which suggests that seasonally driven movement is common within the Neotropics as well as the Afrotropics. We suspect that itinerant behavior occurs commonly during the nonbreeding season in New World songbirds as well. Which species are itinerant, and why others are not, we expect will become clearer in the near future as more detailed studies of the movements of longdistance migrants during the overwintering period become available.

\section{ACKNOWLEDGMENTS}

The online supplementary material is available at dx.doi. org/10.1525/auk.2013.13001. We thank T. E. Ortvad, M. Chrenkova, and especially B. G. Hansen for help in the field. The Copenhagen Bird Ringing Centre with permission from the Danish Nature Agency (J.nr. SN 302-009) approved the study. 
We acknowledge the Danish National Research Foundation for supporting the Center for Macroecology, Evolution and Climate.

\section{Literature Cited}

Afanasyev, V. 2004. A miniature daylight level and activity data recorder for tracking animals over long periods. Memoirs of the National Institute for Polar Research 58:227-233.

Ashmole, N. P. 1963. The regulation of numbers of tropical oceanic birds. Ibis 103b:458-473.

Beason, J. P., C. Gunn, K. M. Potter, R. A. Sparks, and J. W. Fox. 2012. The Northern Black Swift: Migration path and wintering area revealed. Wilson Journal of Ornithology 124:1-8.

BELL, C. P. 1996. The relationship between geographic variation in clutch size and migration pattern in the Yellow Wagtail. Bird Study 43:333-341.

BeLL, C. P. 1997. Leap-frog migration in the Fox Sparrow: Minimizing the cost of spring migration. Condor 99:470-477.

Beyer, H. L. 2012. Geospatial Modelling Environment. [Online.] Available at www.spatialecology.com/gme.

BLONDEL, J. 1967. Etude d'un cline chez le rouge-queue à front blanc phoenicurus phoenicurus l. La variation de la longueur de l'aile, son utilisation dans l'étude des migrations. Alauda 35:83-105, 163-193.

Catry, I., M. P. Dias, T. Catry, V. Afanasyev, J. Fox, A. M. A. FranCO, AND W. J. SutherLAND. 2011. Individual variation in migratory movements and winter behaviour of Iberian Lesser Kestrels Falco naumanni revealed by geolocators. Ibis 153: 154-164.

Cramp, S., Ed. 1988. The Birds of the Western Palearctic, vol. 5: Tyrant Flycatchers to Thrushes. Oxford University Press, New York.

Delmore, K. E., J. W. FoX, And D. E. IRWIn. 2012. Dramatic intraspecific differences in migratory routes, stopover sites and wintering areas, revealed using light-level geolocators. Proceedings of the Royal Society of London, Series B 279:4582-4589.

Durbin, J., AND G. S. WATSON. 1950. Testing for serial correlation in least squares regression. 1. Biometrika 37:409-428.

Elgood, J. H., R. E. Sharland, AND P. Ward. 1966. Palaearctic migrants in Nigeria. Ibis 108:84-116.

FaAborg, J., R. T. Holmes, A. D. Anders, K. L. Bildstein, K. M. Dugger, S. A. Gauthreaux, JR., P. Heglund, K. A. Hobson, A. E. JAHN, D. H. JohnSON, AND OTHERs. 2010. Recent advances in understanding migration systems of New World land birds. Ecological Monographs 80:3-48.

Fox, J. W. 2010. Geolocator Manual, version 8. British Antarctic Survey, Cambridge, United Kingdom. [Online.] Available at www. antarctica.ac.uk/engineering/geo_downloads/Geolocator_manual_v8.pdf.

Fraser, K. C., B. J. M. Stutchbury, C. Silverio, P. M. Kramer, J. Barrow, D. Newstead, N. Mickle, B. F. Cousens, J. C. Lee, D. M. MORRISON, AND OTHERs. 2012. Continent-wide tracking to determine migratory connectivity and tropical habitat associations of a declining aerial insectivore. Proceedings of the Royal Society of London, Series B 279:4901-4906.

FrY, C. H. 1965. The birds of Zaria. II. Palaearctic migrants. Bulletin of the Nigerian Ornithologists' Society 6:35-44.
Fudickar, A. M., M. Wikelski, ANd J. PARtecke. 2012. Tracking migratory songbirds: Accuracy of light-level loggers (geolocators) in forest habitats. Methods in Ecology and Evolution 3:47-52.

Hake, M., N. Kjellén, and T. Alerstam. 2003. Age-dependent migration strategy in Honey Buzzards Pernis apivorus tracked by satellite. Oikos 103:385-396.

Heckscher, C. M., S. M. Taylor, J. W. Fox, and V. Afanasyev. 2011. Veery (Catharus fuscescens) wintering locations, migratory connectivity, and a revision of its winter range using geolocator technology. Auk 128:531-542.

Hedenström, A., S. Bensch, D. Hasselquist, M. Lockwood, AND U. Ottosson. 1993. Migration, stopover and moult of the Great Reed Warbler Acrocephalus arundinaceus in Ghana, West Africa. Ibis 135:177-180.

HiLl, R. D. 1994. Theory of geolocation by light levels. In Elephant Seals: Population Ecology, Behaviour, and Physiology (B. J. Le Boeuf and R. M. Laws, Eds.). University of California Press, Berkeley.

Jahn, A. E., D. J. Levey, And K. G. Smith. 2004. Reflections across hemispheres: A system-wide approach to New World bird migration. Auk 121:1005-1013.

JONES, P. J. 1995. Migration strategies of Palearctic passerines in Africa. Israel Journal of Zoology 41:393-406.

LACK, D., AND R. E. MoREAU. 1965. Clutch-size in tropical passerine birds of forest and savanna. Oiseau 35:76-89.

LACK, P. C. 1986. Diurnal and seasonal-variation in biomass of arthropods in Tsavo East-National Park, Kenya. African Journal of Ecology 24:47-51.

Liechti, F., S. Komenda-Zehnder, And B. Bruderer. 2012. Orientation of passerine trans-Sahara migrants: The directional shift ('Zugknick') reconsidered for free-flying birds. Animal Behaviour 83:63-68.

Lisovski, S., C. M. Hewson, R. H. G. Klaassen, F. KornerNievergelt, M. W. Kristensen, and S. Hahn. 2012. Geolocation by light: Accuracy and precision affected by environmental factors. Methods in Ecology and Evolution 3:603-612.

Moreau, R. E. 1972. The Palaearctic-African Bird Migration Systems. Academic Press, London.

Morton, E. S. 1977. Intratropical migration in Yellow-green Vireo and Piratic Flycatcher. Auk 94:97-106.

Naef-Daenzer, B. 2007. An allometric function to fit leg-loop harnesses to terrestrial birds. Journal of Avian Biology 38:404-407.

Pearson, D. J., And G. C. BACKhurst. 1976. The southward migration of Palaearctic birds over Ngulia, Kenya. Ibis 118:78-105.

Pearson, D. J., AND P. C. LACK. 1992. Migration patterns and habitat use by passerine and near-passerine migrant birds in eastern Africa. Ibis 134 (Supplement s1):89-98.

Pettorelli, N., J. O. Vik, A. Mysterud, J.-M. Gaillard, C. J. TuCKer, AND N. C. Stenseth. 2005. Using the satellite-derived NDVI to assess ecological responses to environmental change. Trends in Ecology \& Evolution 20:503-510.

R Development Core Team. 2011. R: A Language and Environment for Statistical Computing. R Foundation for Statistical Computing, Vienna, Austria.

SAlEWSKI, V., F. BAIRLEIN, AND B. LeISlER. 2002. Different wintering strategies of two Palearctic migrants in West Africa-A consequence of foraging strategies? Ibis 144:85-93. 
Tøttrup, A. P., R. H. G. Klahassen, M. W. Kristensen, R. Strandberg, Y. Vardanis, Å. Lindström, C. RahbeK, T. Alerstam, And K. Thorup. 2012a. Drought in Africa caused delayed arrival of European songbirds. Science 338:1307.

Tøttrup, A. P., R. H. G. KlaAssen, R. Strandberg, K. Thorup, M. W. Kristensen, P. S. Jorgensen, J. Fox, V. Afanasyev, C. RahbeK, And T. Alerstam. 2012b. The annual cycle of a transequatorial Eurasian-African passerine migrant: Different spatiotemporal strategies for autumn and spring migration. Proceedings of the Royal Society of London, Series B 279:1008-1016.

Trierweiler, C., W. C. Mullié, R. H. Drent, K. M. Exo, J. Komdeur, F. Bairlein, A. Harouna, M. De Bakker,
B. J. KoKs, And B. SAndercock. 2013. A Palaearctic migratory raptor species tracks shifting prey availability within its wintering range in the Sahel. Journal of Animal Ecology 82: $107-120$.

United NAtions. 2012. UN relief coordinator warns over humanitarian crisis in Africa's drought-hit Sahel. UN News Centre. [Online.] Available at www.un.org/apps/news/story. asp?NewsID $=42085$.

Zar, J. H. 2010. Biostatistical Analysis, 5th ed. Pearson Education, Upper Saddle River, New Jersey.

Associate Editor: M. T. Murphy 